\title{
Betulinic acid exerts potent antitumor effects on paclitaxel-resistant human lung carcinoma cells (H460) via G2/M phase cell cycle arrest and induction of mitochondrial apoptosis
}

\author{
XIAO-KAI ZHAN ${ }^{1-3},{\text { JUN-LING } \mathrm{LI}^{3}, \text { SEN ZHANG }}^{4}$, PU-YUAN XING ${ }^{3}$ and MENG-FAN XIA ${ }^{5}$ \\ ${ }^{1}$ Department of Hematology and Oncology, Beijing Chaoyang Hospital, \\ Capital Medical University, Beijing 100043; ${ }^{2}$ Department of Oncology, Beijing Friendship Hospital, \\ Capital Medical University, Beijing 100050; ${ }^{3}$ Department of Medical Oncology, National Cancer Center/Cancer Hospital, \\ Chinese Academy of Medical Sciences and Peking Union Medical College, Beijing 100021; ${ }^{4}$ Department of \\ Pharmacology, State Key Laboratory of Bioactive Substance and Function of Natural Medicines, \\ Institute of Material Medicine, Chinese Academy of Medical Sciences and Peking Union Medical College, Beijing 100005; \\ ${ }^{5}$ School of Basic Medical Sciences, Peking University Health Science Center, Beijing 100083, P.R. China
}

Received April 2, 2017; Accepted December 12, 2017

DOI: $10.3892 / 01.2018 .9097$

\begin{abstract}
Betulinic acid is a pentacyclic plant compound obtained from the bark of white birch trees and has been demonstrated to exhibit notable pharmacological properties. In the present study, the anticancer potential of betulinic acid on paclitaxel-resistant lung cancer cell line (H460) was evaluated. Cell viability was evaluated by an MTT assay, and a clonogenic assay was performed to assess the effects on cancer cell colony formation. DAPI staining using fluorescence microscopy and flow cytometry were employed to evaluate the effects of betulinic acid on apoptosis. The effects of betulinic acid on the cell cycle and mitochondrial membrane potential were also evaluated by flow cytometry. The effects of betulinic acid on the protein expression of B-cell lymphoma-2 (Bcl-2)/Bcl-2-associated X (Bax) were evaluated by western blot analysis. The results of the present study indicated that the half-maximal inhibitory concentration value of betulinic acid on paclitaxel-resistant H460 lung cancer cells was $50 \mu \mathrm{M}$. The treatment with betulinic acid was able to inhibit the colony formation potential in a dose-dependent manner. A lower cytoxicity by betulinic acid against normal human epithelial FR2 cells was observed compared with H460 cells. The betulinic acid exerted anticancer activity via the induction of apoptosis by regulating the Bcl-2/Bax signaling pathway. Additionally, treatment with betulinic acid resulted in cell cycle arrest of paclitaxel-resistant lung cancer $\mathrm{H} 460$
\end{abstract}

Correspondence to: Dr Jun-Ling Li, Department of Medical Oncology, National Cancer Center/Cancer Hospital, Chinese Academy of Medical Sciences and Peking Union Medical College, 17 Panjiayuan Nanli, Beijing 100021, P.R. China

E-mail: junlingli56@hotmail.com

Key words: lung cancer, drug resistance, apoptosis, cell cycle arrest cells at the G2/M phase. Betulinic acid was also reported to cause reductions in the mitochondrial membrane potential in a dose-dependent manner. In conclusion, the results of the present study indicated that betulinic acid may be a useful drug candidate for the management of drug-resistant lung cancer.

\section{Introduction}

Lung cancer is one of the major causes of cancer-associated mortality, particularly in China $(1,2)$. The increase in the frequency of cancer, the shortage of curative treatments and the severe side effects associated with synthetic drugs (2) has made it important to investigate novel and more effective molecules. Recently, there has been an increasing interest in the use of plant-derived natural products worldwide due to fewer side effects. Natural products have gained notable importance as anticancer agents due to fewer side effects. Betulinic acid is a pentacyclic compound plant obtained from the bark of white-barked birch trees (3-5). Betulinic acid has been demonstrated to exhibit notable pharmacological properties. For instance, betulinic acid has been reported to exhibit antitumor properties against various types of cancer cells, including breast and liver cancer cells (6). Additionally, Native Americans have used bark of white birch as a folk medicine for the treatment of cancer. With the increase in the incidence of drug-resistance, the treatment and management of cancer has become very difficult (4). In the present study, the effects of betulinic acid, a natural product, on human lung cancer cells were determined. The half-maximal inhibitory concentration $\left(\mathrm{IC}_{50}\right)$ of betulinic acid was detected at $50 \mu \mathrm{M}$. Of note, the results of the present study indicated that betulinic acid exhibited marked anticancer activity. It was observed that treatment with betulinic acid was able to induce apoptosis in human lung cancer H460 cells, alter mitochondrial membrane potential (MMP) and cause cell cycle arrest. Treatment with 
betulinic acid was able to downregulate the expression of B-cell lymphoma-2 (Bcl-2) and upregulate the expression of Bcl-2-associated X (Bax). Collectively, betulinic acid may beauseful drug candidate for the management of drug-resistant lung cancer.

\section{Materials and methods}

Chemicals, reagents and cell culture conditions. Betulinic acid, propidium iodide (PI), RNase A Triton X-100 and dimethyl sulfoxide (DMSO) were obtained from Sigma-Aldrich (Merck KGaA, Darmstadt, Germany). All primary and secondary antibodies were purchased from Santa Cruz Biotechnology Inc. (Dallas, TX, USA). The fluorescent probes (dichloro-dihydro-fluorescein diacetate DCFH-DA, DiOC $_{6}$ and DAPI), fetal bovine serum (FBS), RPMI-1640 medium, L-glutamine and antibiotics were obtained from Invitrogen (Thermo Fisher Scientific, Inc., Waltham, MA, USA). Paclitaxel-resistant human lung cancer cell line (H460) and non-cancerous FR2 cells were procured from Cancer Research Institute of Beijing (Beijing, China), which were maintained in Dulbecco's modified Eagle's medium and was supplemented with $10 \%$ FBS and antibiotics $(100 \mu \mathrm{g} / \mathrm{ml}$ streptomycin and $100 \mathrm{U} / \mathrm{ml}$ penicillin $\mathrm{G}$ ) in incubator at $37^{\circ} \mathrm{C}$ (5\% $\mathrm{CO}_{2}$ and $95 \%$ air).

MTT and colony formation assay. The cytotoxic effect of betulinic acid in paclitaxel-resistant human lung H460 cancer cells was determined using an MTT assay. The cells were cultured at $1 \times 10^{6}$ cells per well in 96-well plates for a time period of $12 \mathrm{~h}$ and then administrated with varying concentrations of betulinic acid $(0-500 \mu \mathrm{M})$ for $48 \mathrm{~h}$. MTT solution $(20 \mu \mathrm{l})$ was added to each well. Prior to the addition of $500 \mu \mathrm{l}$ DMSO, the media was completely removed and replaced with fresh media. To solubilize MTT formazan crystals, $500 \mu 1$ DMSO was added. ELISA plate reader was used for the determination of optical density at $570 \mathrm{~nm}$. H460 lung cancer cells were then subjected to $0,25,50$ and $100 \mu \mathrm{M}$ betulinic acid for further experiments. To evaluate colony formation, lung cancer H460 cells at the exponential growth phase were harvested and counted with a hemocytometer. The cells were plated at 200 cells per well. This was followed by incubation for a time period of $48 \mathrm{~h}$ at $37^{\circ} \mathrm{C}$ to allow the cells to adhere and then various doses $(0,25,50$ and $100 \mu \mathrm{M})$ of betulinic acid were added. Following administration of betulinic acid, the cells were again incubated for 6 days at $37^{\circ} \mathrm{C}$ and washed with PBS. Methanol was used to fix the colonies at $-20^{\circ} \mathrm{C}$ for $4 \mathrm{~min}$ and then stained with crystal violet at room temperature for $\sim 30 \mathrm{~min}$ prior to analysis under a light microscope (10 fields).

Detectionofapoptosisandestimationofapoptoticpopulations. Paclitaxel-resistant $\mathrm{H} 460$ cells (density, $2 \times 10^{5}$ cells/well) that were plated in 6-well plates were administrated with $0,25,50$ and $100 \mu \mathrm{M}$ betulinic acid for $48 \mathrm{~h}$ at $37^{\circ} \mathrm{C}$. The cells were harvested by trypsinization and fixed with acetic acid and methanol $(1: 3)$ for $6 \mathrm{~h}$ at $-20^{\circ} \mathrm{C}$. Following incubation at $-20^{\circ} \mathrm{C}$ for $6 \mathrm{~h}$, the cells were centrifuged for $10 \mathrm{~min}$ at $8,000 \mathrm{x} \mathrm{g}$ at $4^{\circ} \mathrm{C}$ and pellets were resuspended in methanol:acetic acid (1:3). The cells were then plated on a chilled glass slide. DAPI was added for $20-30 \mathrm{~min}$ at $25^{\circ} \mathrm{C}$ in the dark at a concentration of $1 \mu \mathrm{g} / \mathrm{ml}$, and the images were captured using fluorescence microscope (excitation wavelength, $488 \mathrm{~nm} ; 10$ different fields). For Annexin V/PI staining, the cells were harvested and stained with Annexin V/PI for 15 min in dark at room temperature. Subsequently, analysis was performed with a flow cytometer (IX-70; Olympus Corporation, Tokyo, Japan) as previously described (7).

Cell cycle distribution of $H 460$ cells. The cells were seeded into 6 -well plates $\left(2 \times 10^{5}\right.$ cells/well), and betulinic was administrated to the cells at $0,25,50$ and $100 \mu \mathrm{M}$, followed by $24 \mathrm{~h}$ of incubation at $37^{\circ} \mathrm{C}$. DMSO was used as a control. For estimation of the DNA content, PBS was used to wash the cells, which were then fixed in ethanol at $-20^{\circ} \mathrm{C}$ for $24 \mathrm{~h}$. This was followed by re-suspension in PBS, containing $40 \mu \mathrm{g} / \mathrm{ml}$ PI, RNase A $(0.1 \mathrm{mg} / \mathrm{ml})$ and Triton X-100 $(0.1 \%)$, for $30 \mathrm{~min}$ in a dark room at $37^{\circ} \mathrm{C}$. Subsequently, analysis was conducted with a flow cytometer (IX-70; Olympus Corporation). The estimated percentage of cells in each phase of the cell cycle was quantified using WinMDI software version 2.0 (Informer Technologies, Inc., Los Angeles, CA, USA).

Determination of MMP. H460 cells were seeded at a density of $2 \times 10^{5}$ cells/well in a 6 -well plate, which were maintained for $24 \mathrm{~h}$ and treated with $50 \mu \mathrm{M}$ betulinic acid for $0,12,24$ and $48 \mathrm{~h}$ at $37^{\circ} \mathrm{C}$ in $5 \% \mathrm{CO}_{2}$ and $95 \%$ air. Thereafter, the cells from all treatment groups were collected, washed twice with PBS and re-suspended in $500 \mu 1$ 3,3'-dihexyloxacarbocyanine iodide $(1 \mu \mathrm{mol} / \mathrm{l})$ for $\mathrm{MMP}$ at $37^{\circ} \mathrm{C}$ in a dark room for $30 \mathrm{~min}$. The samples were then analyzed immediately using a fluorescence microscope (IX-70; Olympus Corporation) and a flow cytometer with WinMDI software version 2.0 (Informer Technologies, Inc.).

Western blot analysis. The betulinic acid-treated cells (concentration, 0, 25, 50 and $100 \mu \mathrm{M}$ ) were harvested and lysed in lysis buffer [20 mM 4-(2-hydroxyethyl)-1-pip erazineethanesulphonic acid, $350 \mathrm{mM} \mathrm{NaCl}, 20 \%$ glycerol, $1 \%$ Nonidet P 40, $1 \mathrm{mM} \mathrm{MgCl}_{2}, 0.5 \mathrm{mM}$ EDTA, $0.1 \mathrm{mM}$ EGTA, $1 \mathrm{mM}$ DTT, $1 \mathrm{mM}$ PMSF, protease inhibitor cocktail and phosphatase inhibitor cocktail]. The protein concentrations of the lysates were quantified by a bicinchoninic acid assay using specific antibodies. $\beta$-actin was used as a control. From each sample, equal quantities of protein $(0.5 \mu \mathrm{g})$ were loaded and separated by electrophoresis on a $12 \%$ denaturing SDS gel. Subsequently, the proteins were transferred onto polyvinylidene difluoride membranes (pore size, $0.45 \mu \mathrm{m}$ ). Following transfer, the membranes were blocked with $3 \%$ bovine serum albumin (Thermo Fisher Scientific, Inc.) in tris-phosphate-buffered saline (200 mM Tris/pH 7.0, 1.37 M $\mathrm{NaCl}$ and $1 \%$ Tween-20) for $1 \mathrm{~h}$ at room temperature. The membranes were then incubated with appropriate primary antibodies (rabbit polyclonal $\beta$-actin; sc-58673, Bax; sc-6236, $\mathrm{BCl} 2$; sc-509) overnight at $4^{\circ} \mathrm{C}$, followed by incubation with horseradish peroxidase-conjugated alkaline phosphatase secondary antibody (sc-2372; dilution 1:1,000) for $1 \mathrm{~h}$ at room temperature. Super Signal West Dura Extended Duration Chemiluminescent substrate was used for the 

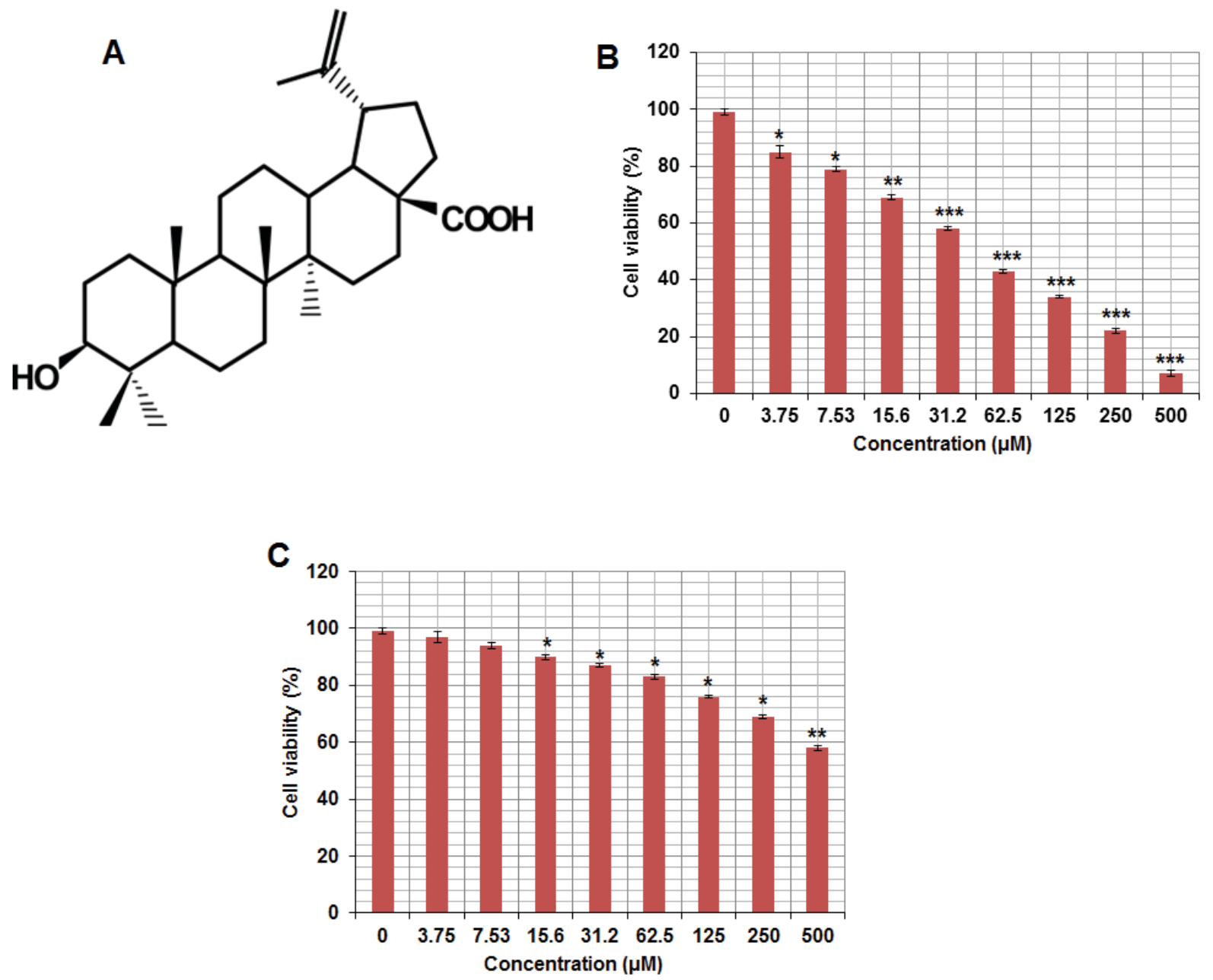

Figure 1. (A) Chemical structure of betulinic acid. (B) Effect of indicated doses of betulinic acid on paclitaxel-resistant $\mathrm{H} 460$ lung cancer cells. (C) Effect of indicated doses of betulinic acid on non-cancerous FR2 human epithelial cells. All experiments are representative of three biological replicates \pm standard deviation. ${ }^{*} \mathrm{P}<0.01,{ }^{* *} \mathrm{P}<0.001,{ }^{* * *} \mathrm{P}<0.0001 ; \mathrm{H} 460$ lung cells vs. the control FR-2 cells.

enhanced chemiluminescence reaction, and the signal was detected and quantified using the ImageQuantLAS4000 imaging system (GE Healthcare Life Sciences, Little Chalfont, UK).

Statistical analysis. All experiments were conducted in triplicate and expressed as the mean \pm standard deviation. Statistical analysis was carried out using a Student's t-test and one-way analysis of variance followed by Tukey's test. GraphPad prism software (version 5.0; GraphPad Software, Inc., La Jolla, CA, USA) was used. $\mathrm{P}<0.01$ was considered to indicate a statistically significant difference.

\section{Results}

Cytotoxic potential of betulinic acid on paclitaxel-resistant lung $H 460$ cancer cells. The chemical structure of betulinic acid is displayed in Fig. 1A. The cytotoxicity of betulinic acid on the paclitaxel-resistant human lung cancer cell line H460 was evaluated. The results of the MTT assay revealed that betulinic acid exhibited concentration-dependent anti-proliferative activity on $\mathrm{H} 460$ cells. The $\mathrm{IC}_{50}$ of betulinic acid on paclitaxel-resistant lung $\mathrm{H} 460$ cells was detected to be $50 \mu \mathrm{M}$ (Fig. 1B). Betulinic acid exhibited a lower cytoxicity on normal human epithelial FR2 cells compared with H460 cells (Fig. 1C). In the colony formation assay, the cells were treated with $0,25,50$ and $100 \mu \mathrm{M}$ betulinic acid, respectively. It was observed that the administration of betulinic acid was able to reduce the number of colonies in a dose-dependent manner (Fig. 2). Colony formation was reduced by $\leq 78 \%$ at $100 \mu \mathrm{M}$ vs. untreated control.

Betulinic acid induces apoptosis in paclitaxel-resistant human H460 lung cancer cells. DAPI staining indicated that betulinic acid was able to induce apoptosis in $\mathrm{H} 460$ paclitaxel-resistant cancer cells in a dose-dependent manner (Fig. 3). At 50 and $100 \mu \mathrm{M}$ of betulinic acid, apoptotic cells were notably visible. In order to confirm apoptotic cell death that was induced by betulinic acid, Annexin V/PI staining was conducted following the treatment of $\mathrm{H} 460$ cells with $0,25,50$ and $100 \mu \mathrm{M}$. Flow cytometric results revealed that the percentage of apoptotic cell population increased to $7.82,17.05$ and $36.07 \%$ in paclitaxel-resistant human $\mathrm{H} 460$ lung cancer cells after $48 \mathrm{~h}$, compared with the untreated control at 25, 50 and $100 \mu \mathrm{M}$, respectively (Fig. 4). Therefore, the results indicated that treatment with betulinic acid resulted in apoptotic cell death in paclitaxel-resistant human H460 cancer cells in a concentration-dependent manner. 

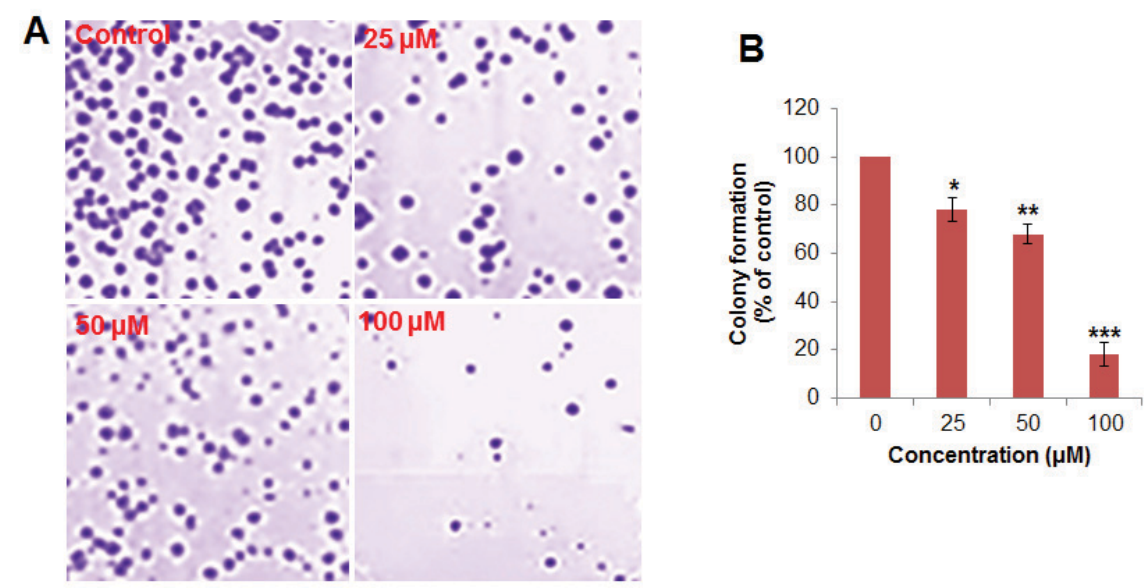

Figure 2. Colony forming potential of betulinic acid paclitaxel cancer H460 cells. (A) Plates showing cell colonies that were treated with betulinic acid at the indicated doses. (B) Quantification of the colonies. All experiments are representative of three biological replicates and expressed as the mean \pm standard deviation. ${ }^{*} \mathrm{P}<0.01,{ }^{* * *} \mathrm{P}<0.001,{ }^{* * * *} \mathrm{P}<0.0001$ vs. control.
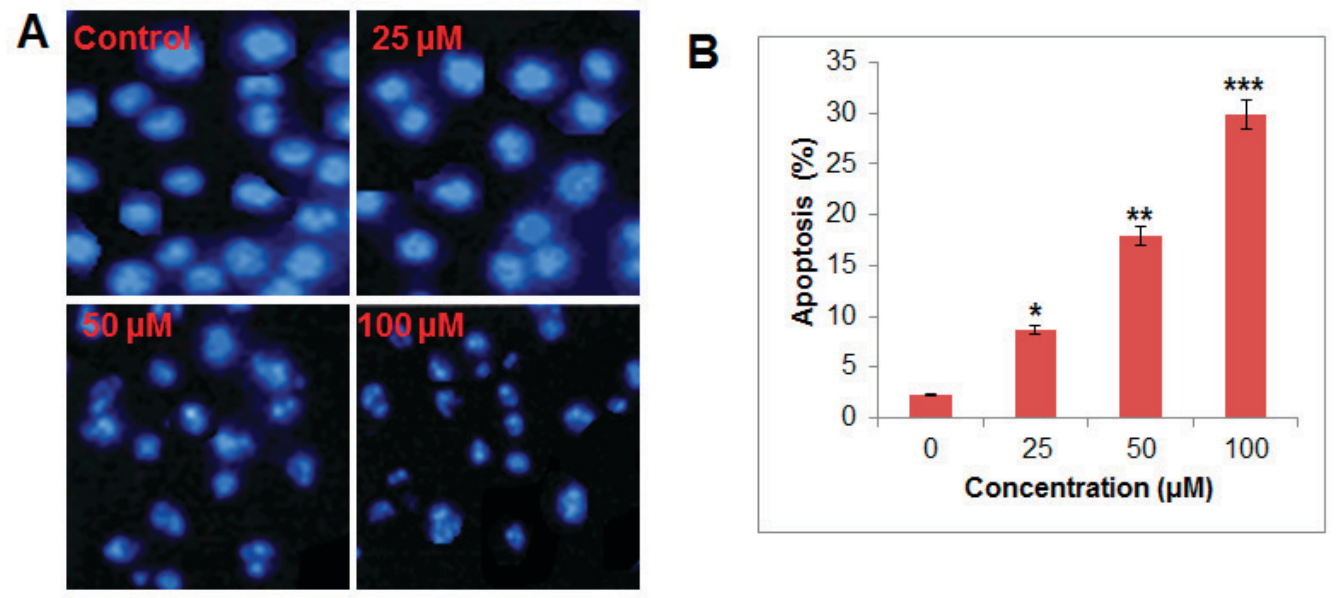

Figure 3. Induction of apoptosis by betulinic acid at indicated doses as depicted by (A) DAPI staining and (B) flow cytometry. All experiments are representatives of three biological replicates and expressed as the mean \pm standard deviation. ${ }^{*} \mathrm{P}<0.01,{ }^{* *} \mathrm{P}<0.001,{ }^{* * *} \mathrm{P}<0.0001$ vs. control.
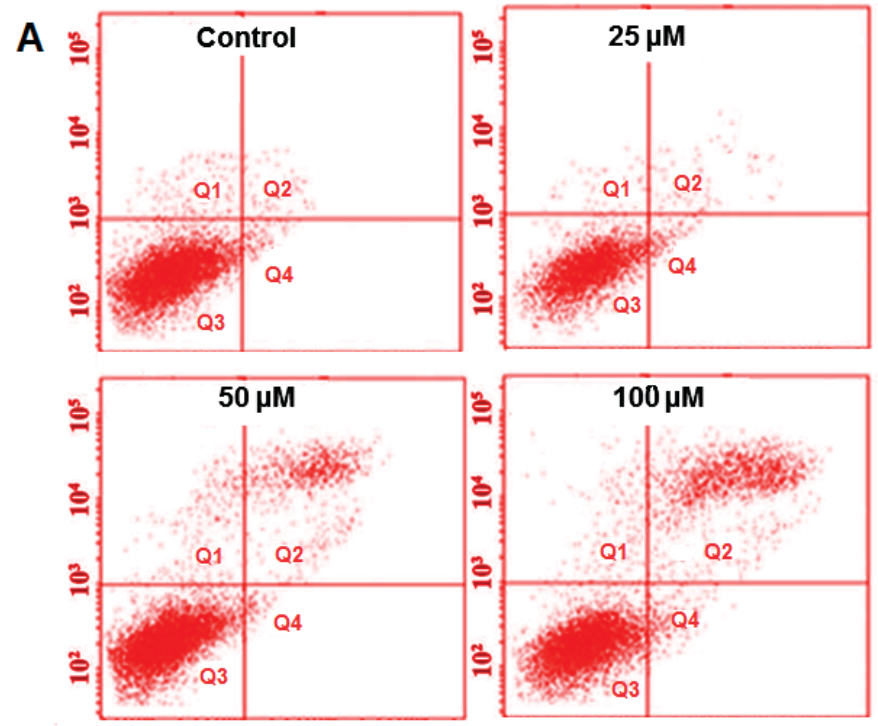



Figure 4. Analysis of cell apoptosis in betulinic acid-treated paclitaxel-resistant lung cancer H460 cells by (A) Annexin V/propidium iodide staining (B) Quantification of the apoptotic cell populations. All experiments are representatives of three biological replicates and expressed as the mean \pm standard deviation. ${ }^{*} \mathrm{P}<0.01,{ }^{* *} \mathrm{P}<0.001,{ }^{* * *} \mathrm{P}<0.0001$ vs. control. 

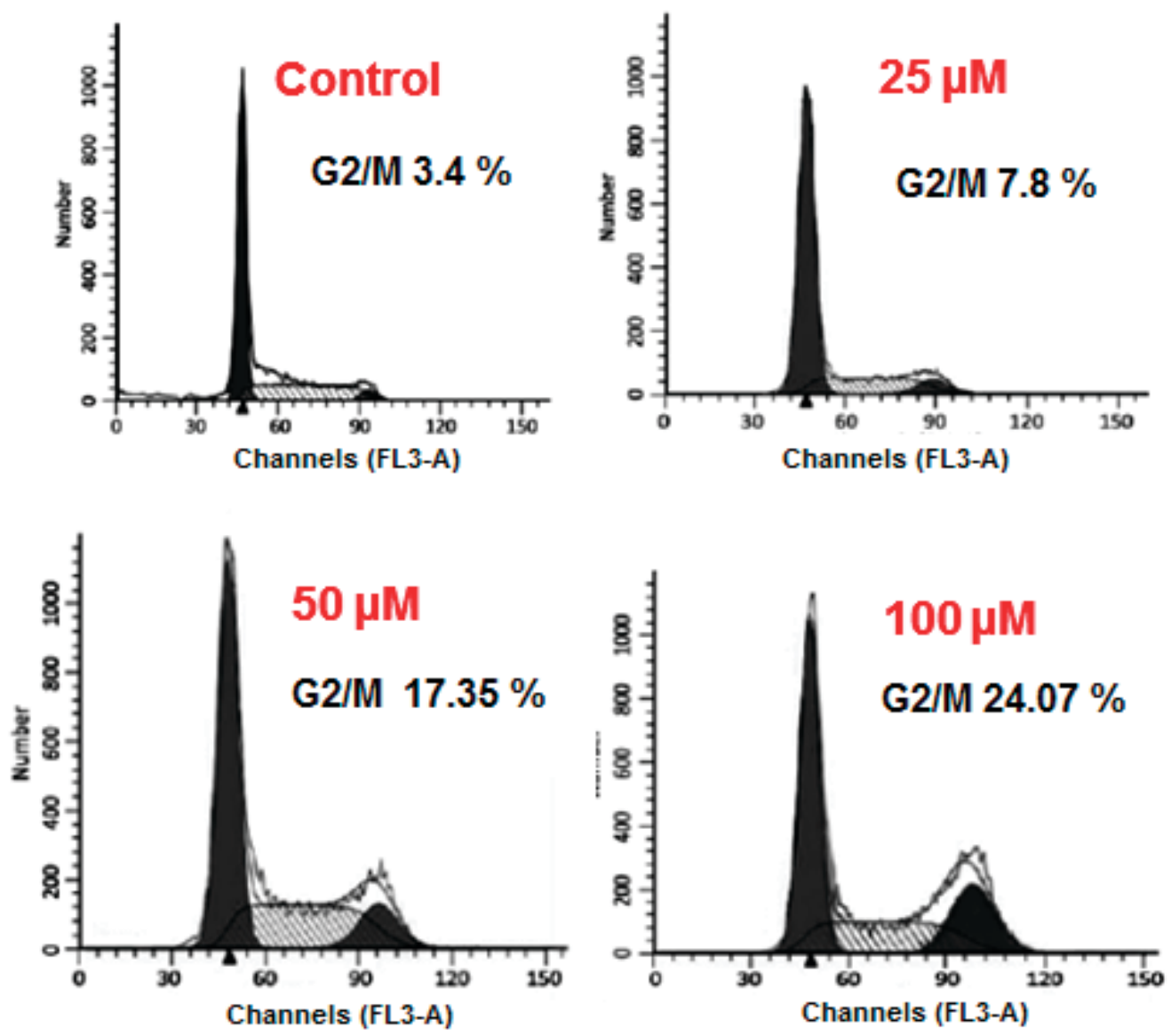

Figure 5. Effect of the indicated doses of betulinic acid on cell cycle distribution of $\mathrm{H} 460$ cancer cells. All experiments are representative of three biological replicates.
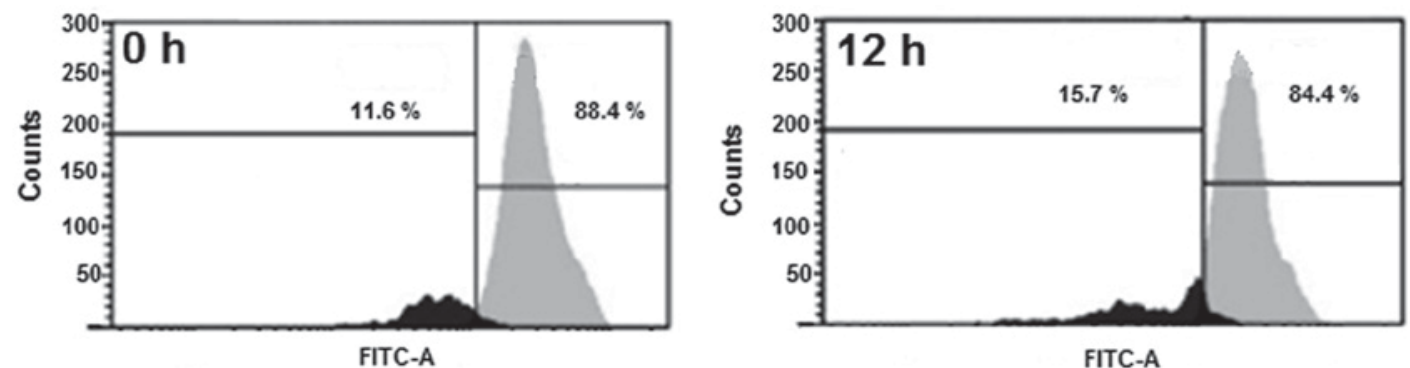

FITC-A


FITC-A

FITC-A

Figure 6. Effect of $50 \mu \mathrm{M}$ betulinic acid at indicated time intervals on mitochondrial membrane potential of paclitaxel-resistant lung cancer H460 cells. All experiments are replicates of three biological replicates. FITC, fluorescein isothiocyanate.

Betulinic acid causes alterations in cell cycle distribution of $H 460$ cancer cells. The results of the present study indicated that betulinic acid may have induced cell cycle arrest of H460 lung cancer cells. It was observed that the percentage of cells was notably increased at G2. G2 arrest was detected following treatment with 25,50 and $100 \mu \mathrm{M}$ 
A

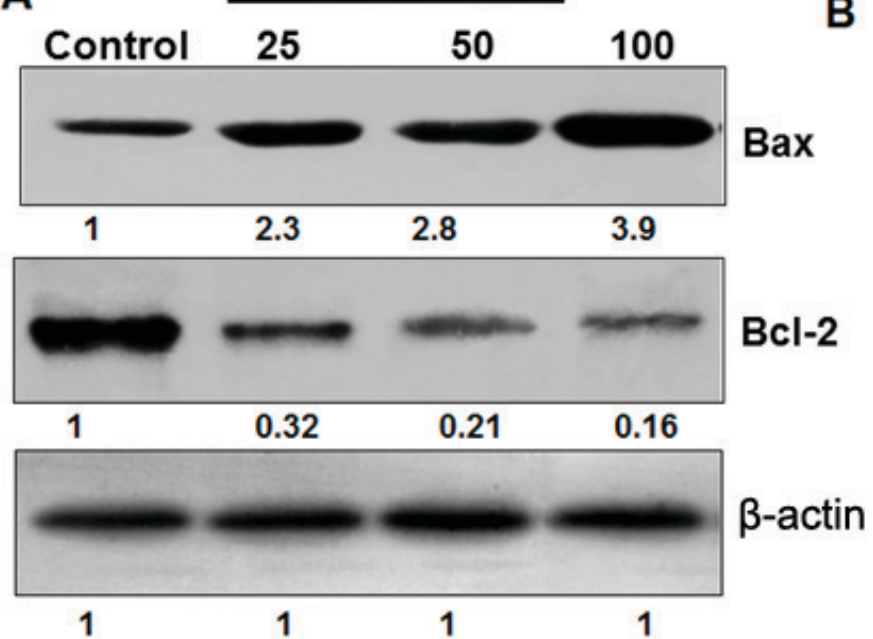

B

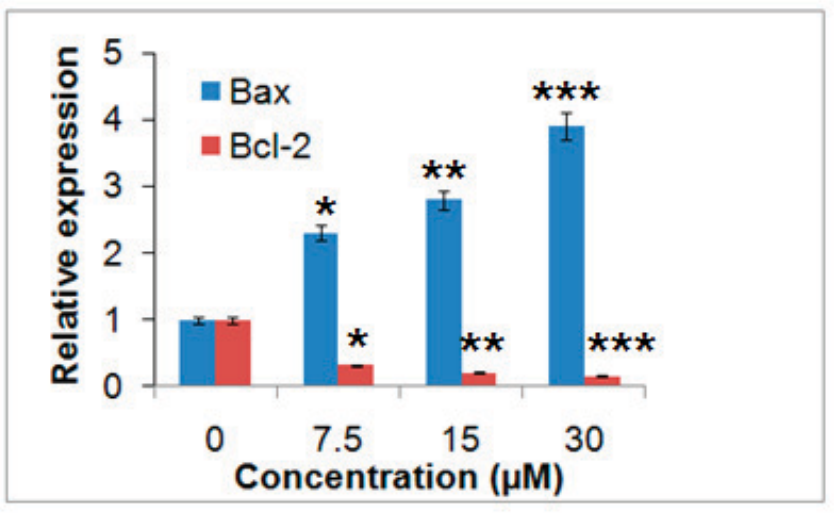

Figure 7. Effect of indicated doses of betulinic acid on the expression of (A) Bcl-2 and Bax proteins by western blotting. (B) Quantification was carried out by densitometric analysis. All experiments are representatives of three biological representatives. Bcl-2, B-cell lymphoma 2; Bax, Bcl-2-associated $\mathrm{X}$. $\mathrm{P}<0.01$, ${ }^{* * *} \mathrm{P}<0.001,{ }^{* * *} \mathrm{P}<0.0001$ vs. control.

betulinic acid (Fig. 5). Additionally, the population of G2 H460 cells was slightly increased at a dose of $25 \mu \mathrm{M}$, markedly elevated at $50 \mu \mathrm{M}$ and highly elevated at $100 \mu \mathrm{M}$ compared with the control. The effect of betulinic acid on the proportion of $\mathrm{H} 460$ cells at $\mathrm{G} 2$ was observed to be dose-dependent.

Betulinic acid induces MMP loss in human H460 lung cancer cells. TheH460 cells were administrated with $50 \mu \mathrm{M}$ betulinic acid for various time intervals, and the levels of MMP were evaluated. A marked reduction in the level of MMP (Fig. 6) was detected in the betulinic acid-treated H460 cells compared with the control. After 12,24 and $48 \mathrm{~h}$, the MMP was observed to be $84.10,75.26$ and $57.14 \%$ compared with the untreated paclitaxel-resistant human H460 lung cancer cells.

Betulinic acid targets the Bcl-2/Bax signaling pathway. The expression levels of Bcl-2and Bax were determined to confirm if betulinic acid induced-apoptosis followed the mitochondrial apoptotic pathway. The findings are presented in Fig. 7. It was observed that the expression of Baxincreased and $\mathrm{Bcl}-2$ decreased following the treatment with betulinic acid, which may have resulted in apoptosis. Compared with the untreated control cells, betulinic acid-treated cells demonstrated a concentration-dependent increase in the $\mathrm{Bax} / \mathrm{Bcl}-2$ ratio.

\section{Discussion}

Lung cancer is one of the most lethal types of cancer detected worldwide and thousands of patients are diagnosed with this disease annually (1). Existing treatment options exhibit effective clinical results, yet numerous cancer-associated mortalities are attributable to lung cancer. In addition, existing treatment options have severe side effects, which negatively affect the quality of life (2). Furthermore, the development of drug resistance has made cancer very difficult to treat (4).
Against this backdrop, molecules from natural sources with limited side effects may prove useful.

In the present study, betulinic acid revealed potential growth-inhibiting activity against paclitaxel-resistant lung H460 cancer cells as evident from the proliferation assay. As reported previously, numerous drugs exhibit antiproliferative effects via the induction of apoptosis. For instance, several chemotherapeutic drugs, including cisplatin, taxol and 5-fluorouracil (8-16) have been reported to alter specific apoptotic pathways. Additionally, resistance to drug may be partially explained by the ability of cancer cells to evade apoptosis (17). To assess whether treatment with betulinic acid induces apoptosis in H460 cells, DAPI staining of betulinic acid-treated cells was performed. It was observed that treatment with betulinic acid was able to induce apoptosis in a concentration-dependent manner. Furthermore, a marked reduction in MMP was observed following treatment with betulinic acid and a concentration-dependent pattern was detected. The results of the present study are in agreement with studies that were conducted previously (16). The results of the present study suggested that treatment with betulinic acid may induce apoptosis by reducing MMP. Several anticancer drugs target cancer cells partly by accumulating high levels of ROS and reducing MMP (17). MMP serves an important role in the induction of apoptosis. For example, capsaicin disrupts MMP and mediates oxidative stress resulting in the apoptosis of pancreatic cancer cells (10-16).

Flow cytometry using PI as a probe was used to analyze the effects of betulinic acid on cell cycle progression in the present study. Treatment with betulinic acid induced G2/M cell cycle arrest and led to a marked increase of G2/M cells in a dose-dependent manner. Furthermore, it was reported that betulinic acid may inhibit H460 cancer cells in a concentration-dependent manner. These findings are promising as it is well established that paclitaxel-resistant lung cancer is one of the cancer types with a high mortality rate, and betulinic acid may a potential compound for treatment (17). 
The effects of betulinic acid on Bcl-2/Bax signaling were investigated using western blot analysis. A concentration-dependent downregulation of $\mathrm{Bcl}-2$ and upregulation of Bax were observed in betulinic acid-treated cells, which may ultimately induce apoptosis.

Collectively, betulinic acid may be a potential candidate for the treatment of lung cancer by regulating the Bcl-2/Bax signaling pathway. With limited drug options available and limited toxicity associated with naturally occurring betulinic acid, this molecule appears to be a viable option, but further investigation is required.

\section{Acknowledgements}

Not applicable.

\section{Funding}

No funding was received.

\section{Availability of data and materials}

The datasets used and/or analysed during the current study are available from the corresponding author on reasonable request.

\section{Authors' contributions}

$\mathrm{XZ}$ and JL conceived and designed the experiments; XZ, JL, SZ, PX and MF performed the experiments; JL and MF analysed the data; XZ JL and SZ drafted the manuscript. All authors reviewed and approved the manuscript.

\section{Ethics approval and consent to participate}

Not applicable.

\section{Patient consent for publication}

Not applicable.

\section{Competing interests}

The authors declare that they have no competing interests.

\section{References}

1. Jemal A, Bray F, Center MM, Ferlay J and Ward E: Global cancer statistics. CA Cancer J Clin 61: 69-90, 2011.
2. Molina JR, Yang P, Cassivi SD, Schild SE and Adjei AA. Non-small cell lung cancer: Epidemiology, risk factors, treatment and survivorship. Mayo Clin Proc 83: 584-594, 2008.

3. Curr Cancer Drug Targets: Targeting apoptosis pathways in cancer therapy. Curr Cancer Drug Targets 4: 569-576, 2004.

4. Degterev A, Boyce M, Yuan JA, Walczak H and Krammer PH: The CD95 (APO-1/Fas) and the TRAIL (APO-2L) apoptosis systems. Exp Cell Res 256: 58-66, 2000.

5. Romashkova JA and Makarov SS: NF-kappaB is a target of AKT in anti-apoptotic PDGF signalling. Nature 401: 86-90, 1999.

6. Fulda S: Betulinic acid: A natural product with anticancer activity. Mol Nutr Food Res 53: 140-146, 2009.

7. Chiang JH, Yang JS, Ma CY, Yang MD, Huang HY, Hsia TC, Kuo HM, Wu PP, Lee TH and Chung JG: Danthron, an anthraquinone derivative, induces dna damage and caspase cascades-mediated apoptosis in snu-1 human gastric cancer cells through mitochondrial permeability transition pores and bax-triggered pathways. Chem Res Toxicol 24: 20-29, 2011.

8. Sun SY, Hail N Jr and Lotan R: Apoptosis as a novel target for cancer chemoprevention. J Natl Cancer Inst 96: 662-672, 2004.

9. Maitra R, Porter MA, Huang S and Gilmour BP: Inhibition of NFkappaB by the natural product Withaferin A in cellular models of Cystic Fibrosis inflammation. J Inflamm 6: 15, 2009.

10. Hissin PJ and Hilf R: A fluorometric method for determination of oxidized and reduced glutathione in tissues. Anal biochem 74: 214-226, 1976

11. Chipuk JE, Bouchier-Hayes L and Green DR: Mitochondrial outer membrane permeabilization during apoptosis: The innocent bystander scenario. Cell Death Diff 13: 1396-1402, 2006.

12. Azuma M, Tamatani T, Ashida Y, Takashima R, Harada K and Sato M: Cisplatin induces apoptosis in oral squamous carcinoma cells by the mitochondria-mediated but not the NF-kappaB-suppressed pathway. Oral Oncol 39: 282-289, 2003.

13. Yoneda K, Yamamoto T and Osaki T: p53- and p21-independent apoptosis of squamous cell carcinoma cells induced by 5-fluorouracil and radiation. Oral Oncol 34: 529-537, 1998.

14. Abal M, Andreu JM and Barasoain I: Taxanes: Microtubule and centrosome targets and cell cycle dependent mechanisms of action. Curr Canc Drug Targs 3: 193-203, 2003.

15. Ferreira CG, Epping M, Kruyt FA and Giaccone G: Apoptosis target of cancer therapy. Clin Cancer Res 8: 2024-2034, 2002.

16. Malaguarnera L: Implications of apoptosis regulators in tumorigenesis. Cancer Met Rev 23: 367-387, 2004.

17. Ding H, Han C, Guo D, Chin YW, Ding Y, Kinghorn AD and D'Ambrosio SM: Selectiveinduction of apoptosis of human oral cancer cell lines by avocado extracts via a ROS-mediated-mechanism. Nutr Cancer 61: 348-356, 2009.

This work is licensed under a Creative Commons Attribution-NonCommercial-NoDerivatives 4.0 International (CC BY-NC-ND 4.0) License. 